\title{
The sequestration of trace elements in pyrite from modern and ancient volcanic-hosted massive sulfide deposits
}

\author{
HANNAH L J GRANT ${ }^{1,2}$, MARK D HANNINGTON ${ }^{1,3}$ AND \\ SVEN PETERSEN ${ }^{1}$ \\ ${ }^{1}$ GEOMAR Helmholtz Center for Ocean Research \\ ${ }^{2}$ British Geological Survey \\ ${ }^{3}$ University of Ottawa \\ Presenting Author: hgrant@bgs.ac.uk
}

The incorporation of the majority of trace ore elements into pyrite from seafloor massive sulfide deposits is systematically predictable regardless of geodynamic setting, metal source, style of deposit, or age (from modern to Precambrian). An extensive database of in-situ laser ablation inductively-coupled plasma mass spectrometry (LA-ICP-MS) analyses compiled from new data and published literature shows that distinct trace element associations correspond not only to source rock but also to specific mechanisms of incorporation into pyrite. Inclusions within pyrite are a major control on relative enrichments of trace elements: sphalerite inclusions control the distribution of $\mathrm{Zn}, \mathrm{Cd}$, $\mathrm{Ga}, \mathrm{In}, \mathrm{Mn},+\mathrm{Tl}, \mathrm{Cu}$-sulfide (likely chalcopyrite) inclusions contain $\mathrm{Cu}, \mathrm{Bi}, \mathrm{Sn},+\mathrm{Te}$, and galena or sulfosalt inclusions contain $\mathrm{Pb}, \mathrm{Ag}, \mathrm{Sb}, \mathrm{As}$, and $\mathrm{Tl}$. The relative importance of these inclusions depends on the availability of the trace metals, which in turn reflect mafic, bimodal, and felsic source rocks. The residence of $\mathrm{Au}$ in pyrite also partly reflects geodynamic setting, which influence the availability of $\mathrm{Bi}, \mathrm{Ag}, \mathrm{Sb}$, and $\mathrm{Te}$ that occur as discrete Au-bearing mineral phases in the pyrite. In contrast, lattice substitution into pyrite is the dominant mechanism of incorporation for $\mathrm{Co}, \mathrm{Ni}, \mathrm{Se}, \mathrm{Te}$, and +As. Surface adsorption processes control the incorporation of $\mathrm{V}, \mathrm{U}$, a portion of $\mathrm{Mo}, \mathrm{Mn}$, and potentially $\mathrm{Tl}$. Trace element distribution in pyrite from active seafloor hydrothermal systems show that there is a strong temperature control, with pyrite formed at higher temperature containing more abundant trace elements associated with $\mathrm{Cu}-$ sulfides, mainly as submicroscopic inclusions, and lowertemperature pyrite containing more elements associated with sphalerite, sulfosalts, and galena. Inclusions appear to be more abundant in pyrite from modern SMS deposits than in pyrite from ancient deposits, which have been affected by secondary remobilization processes and metamorphism. However, certain trace elements are retained in pyrite from ancient deposits, in particular lattice-bound elements such as $\mathrm{Se}$, but also some trace elements associated with primary inclusions. The results show that the chemistry of pyrite is a remarkably good indicator of the chemistry of hydrothermal systems for many trace elements, and is also highly predictable. 